\title{
自励式位相調整器の瞬時值解析による検討
}

\begin{tabular}{|c|c|c|}
\hline 千田 & 卓 & （東北電力株式会神 \\
\hline 佐 藤 & 佳 彦 & (果北電力株式会社) \\
\hline 菅 原 & 徇 & （東北電力株式会社 \\
\hline 木 & (1) & 東芝 \\
\hline & 章 & ( (株) \\
\hline & & （（株） \\
\hline
\end{tabular}

\section{Simulation Study of Unified Power Flow Controller}

Takuji CHIDA, Member, Yoshihiko SATo, Member, Jun SUGAWARA, Member

(Tohoku Electric Power Company)

Ryuuichi MORIKAWA, Member, Yoshiaki TAMURA, Member, Shoichi IROKAWA, Member

( Toshiba Corporation)

The increasing complexity of AC power networks requires a high performance power flow control system in order to obtain a desired power flow and enhance static and dynamic stability. One of the most effective power electronic systems to satisfy these requirements is a UPFC(Unified Power Flow Controller) employing self-commutated converters.

This paper presents basic control strategies and simulation results for the UPFC using EMTP(ElectroMagnetic Transients Program). The simulations were carried out for start and stop operations, power flow change operations in normal system conditions, as well as operations during system fault conditions. Thyristor based bypass switches are used for the protection of the series compensator of the UPFC from system fault currents, and satisfactory protection capability was confirmed.

キーワード：自励式位相調整器，FACTS，直列補賲，潮流制御，系統事故，バイパススイッチ

\section{1.まえがき}

電力系統へのパワーエレクトロニクス技術の適用は，こ れまで直流送電㧍よび静止形無效電力補償装置（SVC）な ど, 他励式変換器によるものが主体であった。しかし，自 己消弧形の電力用半導体素子とその適用技術の進歩により， 自励式変換器の大容量化が進み, 自励式 SVC や可変速揚水 発電機の自励式励磁装置にも適用が広がってきている。

送電線や電源の立地難から系統の安定度は䃝しさを增し ているが，パワーエレクトロニクス技術を用いて送電線の 熱容量の限界まで送電可能とすることを目的とした FACTS (Flexible AC Transmission Systems) の概念が注 目を浴びている(1)。その中でも自励式位相調整器は，系統 の電圧の大きさ，位相，インピーダンスの 3 要素を高速か つ連続的に調整し, 電圧の安定化, 電力動摇の抑制および
自在な潮流制御を可能とする装置として，FACTS の中心 的役割を果たすものと期待されている。

自励式位相調整器に関して, これまで実効值レペルでの 解析により系統に及ぼす勃果の検討結果が報告されている (2)。しかし, 自励式位相調整器を装置として製作し, 実際 の系統に適用するには, 瞬時值レベルの解析により詳細な 回路動作を険討し，様々な運転状況にも対応したシステム 構成とすることと，制御保護技術の確立が不可久である。 特に系統事故時には, 自励式位相調整器を構成する機器が 過電流や過電圧とならず, 極力連転を継続して, 系統安定 化に奇与でさることが好ましい。

本論文では EMTP を使用した瞬時值シミュレーション解 析を行い, 自励式位相調整器の起動・停止や潮流制御など の通常時の運転, および様々な系統事故時の運転が安定に 行えるための，具体的な制御保護方式とシステム構成㭘討 


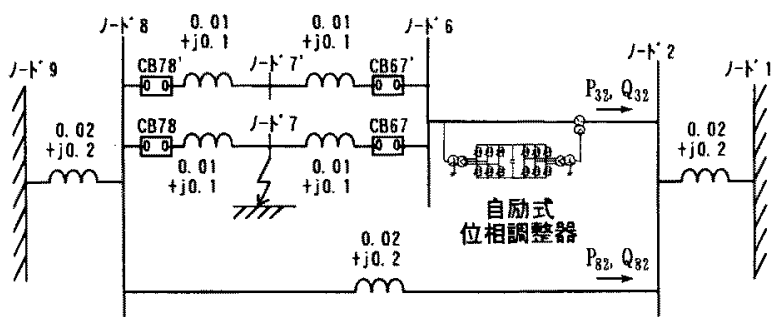

図 1 モデル系統 $(50 \mathrm{~Hz}-5000 \mathrm{MVA}-500 \mathrm{kV}$ base)

Fig.1. Model system used for studies.

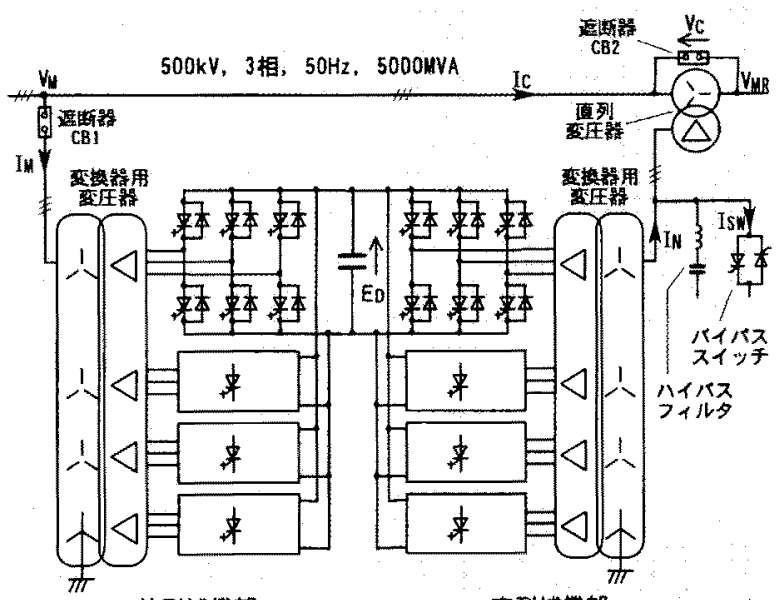

$$
\text { 上，並列補侯部 }
$$

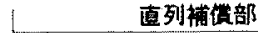

直列補傎部

\begin{tabular}{|c|c|}
\hline 調整容量 & 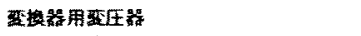 \\
\hline $50 \mathrm{~Hz}_{\mathrm{Z}}-250 \mathrm{NYA}$ & 並列補只部用 \\
\hline 自㢦式要掺器 & $280 \mathrm{MYA}(4 \times 70 \mathrm{MYA}), \approx[\mathrm{X}=20 \%$ \\
\hline 直列悑虽部，亚列補新 & 1 次：5000V(4直列 $\times 125 \mathrm{kV})$ \\
\hline $4 \times 700 \mathrm{NA}-22.5 \mathrm{kV}$ & 2次： $22.5 \mathrm{kV} \times 4$ 堂楾 \\
\hline 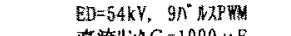 & 西列補织部用 \\
\hline 直流将 $\mathrm{C}=1900 \mu \mathrm{F}$ & $280 \mathrm{MVA}(4 \times 70 M Y A), 81 \mathrm{X}=10 \%$ \\
\hline 直列殁厌器 & 1次: $77 \mathrm{kV}(4$ 直列 $\times 19.25 \mathrm{kV})$ \\
\hline 280WYA. $\%: X=10 \%$ & 2 次：22.5kY X4巻線 \\
\hline 1次 : $16.2 \mathrm{k}$ Y / 相 & ハィハスフィルタ \\
\hline 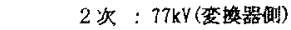 & 同濖次数：31次，容量：12.5NVA \\
\hline
\end{tabular}

図 2 自励式位相調整器の構成之諸元

Fig.2. System configuration of UPFC.

時に留意すべき点を明らかにした。

\section{2. システム構成}

図1は解析に用いたモデル系統でノード 1 とノード9は 無限大母線とした。これらのノードを結ぶ 2 つのルートの 一方に，5,000MVA の系統容量の 5\%に相当する $250 \mathrm{MVA}$ の自励式位相調整器を設置することを想定した。ノード 6 とノード 2 との間に自励式位相調整器を設置することで, どちらか 1 回線が切り離された場合でも潮流制御能力が発 揮できるようにしている。

図 2 に本論文で解析の対象とした自励式位相調整器モデ ルの構成および諸元を示す。自励式位相調整器は, 系統に 並列に接続する並列補償部と，系統に直列に接続する直列 補顀部とから構成され，各々の直流部は結合され共有され

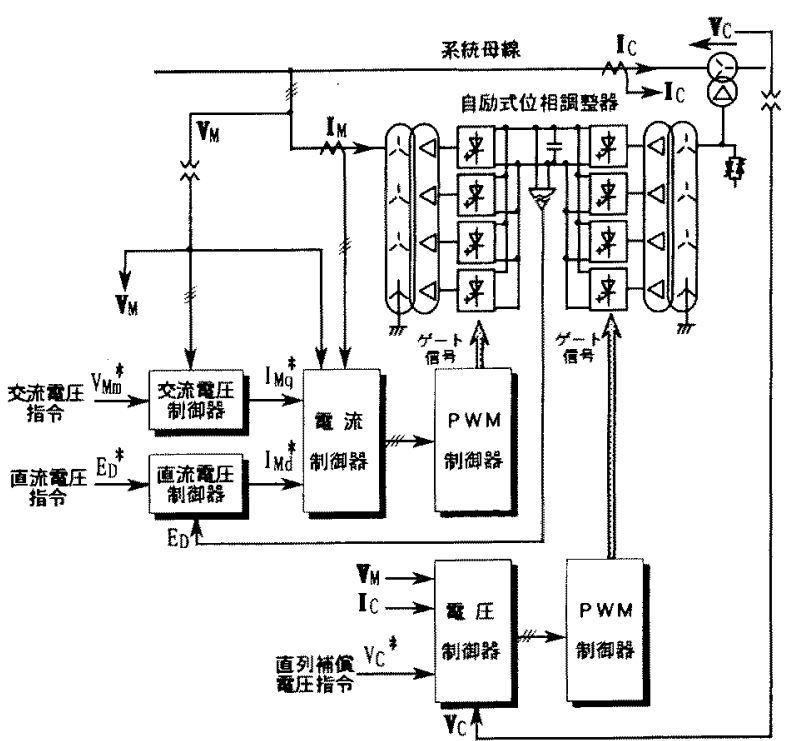

図 3 制御構成

Fig.3. Configuration of the controller.

る。各補償部は種々の構成が考えられるが，ここでは高調 波低減の観点から，雨補偵部とも 9 パルスでPWM(Pulse Width Modulation)制御された 4 つの電圧形自励式変換器 の出力を, 変換器用変庄器によって交流側で 4 段多重化す る構成とした。

さらに直列補償部は, 変換器用変圧器の出力を系統に直 列に直接挿入するのでなく, 別に設けた直列変圧器を介し て挿入する構成とした。この 2 つの变圧器の間にサイリス 夕を用いたバイバススイッチを接続しているが，これは後 述するように, 系統事故時の過電圧・過電流から変換器を 保護するとともに，変換器故障時に系統が分離することを 防止するためである。したがって直列変圧器の巻線比は, 系統故障時の過電流をバイパススイッチのサイリスタの電 流定格に適した電流に変換するように選定される。また直 列変圧器の変换器側の結線も, 後述するように系統の不平 衡事故時に零相電流を変換器用変圧器に流さないようにデ ル夕 $(\Delta)$ としている。

また直列補償部が発生する高調波は，系統のインピーダ ンスに無関保にそのまま系統に直列に挿入されるため，並 列補償部に比較して高調波低減の必要性が高い。ここでは 変換器用変圧器と直列変生器の間に高次の高調波を除去す るためのハイパスフィル夕を設けている。直列変圧器の極 間に設けられた遮断器 CB2 は，直列補償部の起動・停止に 重要な役割を持ち、これについても後述する。

\section{3. 自励式位相調整器の制御方式}

本諭文で解析に使用した自励式位相調整器の制御構成を 図 3 に示す。並列補偵部の制御方式は，自励式 SVC 亡同様 に出力電流 IM 制御して交流電圧の制御と变換器の直流り ンク電圧の制御を行う。自厉式位相調整器の機能を特徽づ 


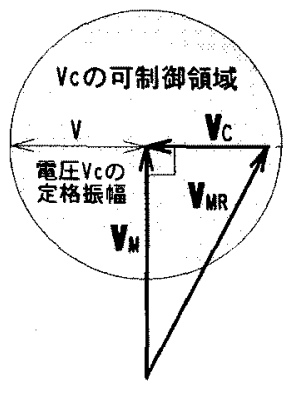

(a ) 位相変圧器モード

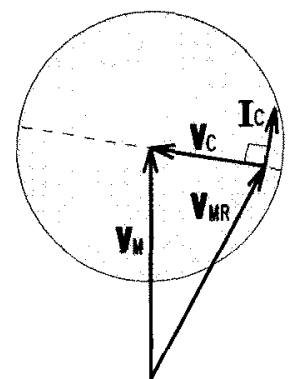

(b) 直列コンデンサモード
図 4 直列補熕部の補償モード

Fig.4. Compensation mode of series compensator.

けるのは直列補償部の制御である。直列補償部は, 直列変 圧器を介して系統に㨂入する直列補償電圧 $\mathrm{V}_{\mathrm{C}}$ の大きさと 位相を自由に制御し，系統の潮流の制御などを行う。

実際には図 3 の電圧制御器の直列補償電圧指令 $V_{C}$ *を决 定する系統潮流制御器が上位制御としてさらに必要である が，ここでは㭘討の対象から除外した。本論文では直列補 償部の基本となる電圧制御器についての検討に着目したた めである。この直列補償電圧の挿入方法の違いにより分類

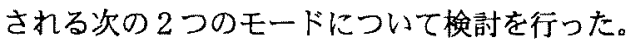

(1) 位相変圧器モード : ( 図4 (a) )

母線電圧 $V_{\mathrm{M}}$ を位相基準にとり， $\mathrm{V}_{\mathrm{M}}$ に対して位相が $90^{\circ}$ 異なった電压 $V_{C}$ を挿入する補償モード。従来の 位相変圧器に相当する。

(2) 直列コンデンサモード : ( 図 4(b))

線路電流 $\mathrm{I}_{\mathrm{C}}$ を位相基準とし，Icに対して位相が $90^{\circ}$ 異なった電圧 $\mathrm{V}_{\mathrm{C}}$ を挿入する補侻モ一ド(3)。直列の 可変コンデンサ, 可変リアクトルと見なせる。

直列コンデンサモードでは淔列補償部と系統との間で有 効電力の授受がないため，並列補償部は直列補償部で発生 する損失分を補償するだけの僅かな有効電力を直列補償部 に供給するだけで良い。しかし系統の通過電流を位相の基 準とするため, 軽負荷特は基準位相が得にくい。一方, 位 相変圧器モードでは系統電圧を位相の基準とするため上記 のような問題はない。しかし潮流の力率が低いときは, 直 列補鰂部之系統との間で有効電力の授受が增大し，直流り ンク電圧維持のために並列補償部によって直列補償部が授 受した有效電力を補償する必要がある。これによる制約の ため, 並列補償部の出力可能な無効電力が減少する。また 上記 2 種類の動作モードの他に, 直列補償部の出力電圧の 大きさと位相を自由に変化させて系統潮流を制御するフリ 一モードもある(4)-(6)。

\section{4. 定常運転}

$\langle 4 \cdot 1\rangle$ 起動・停止自励式位相調整器の起動・停止 シーケンスを図 5 に示す。ただし，図中の時刻および具体 的数值は後記の解析に使用した值である。図 5 に示すよう

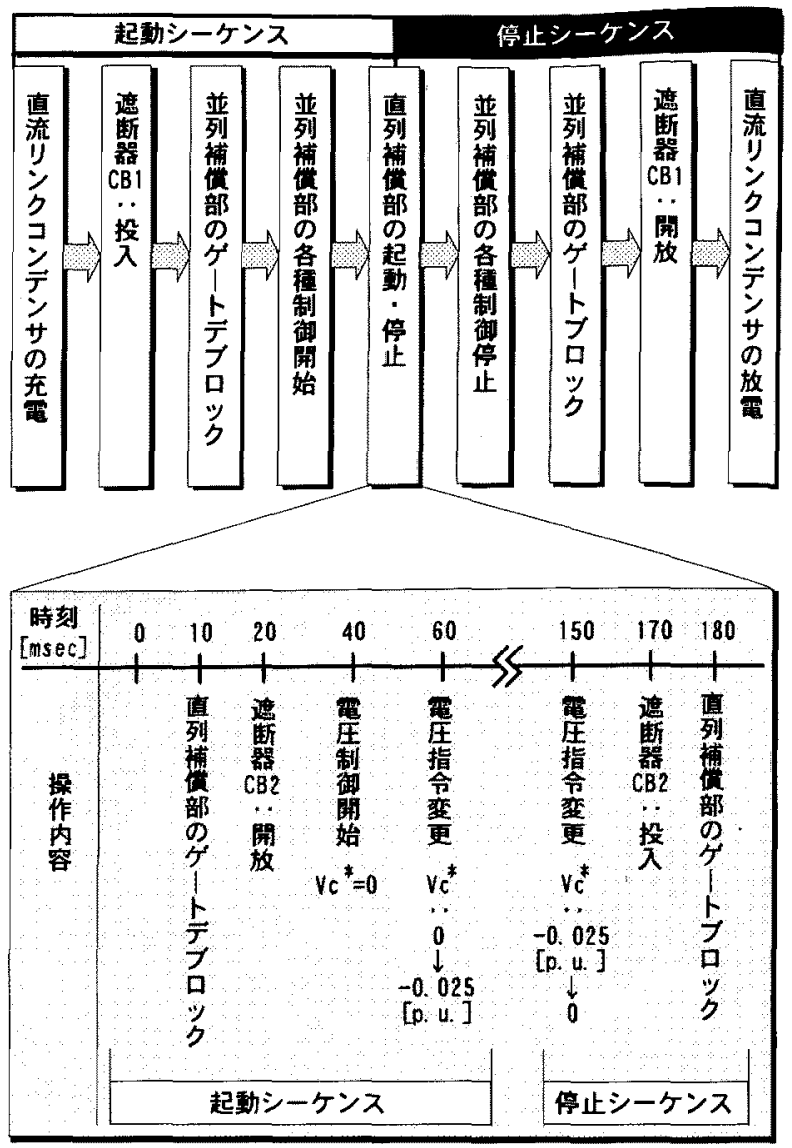

図 5 起動・停止シーケンス

Fig.5. Sequence of start and stop operations.

に自励式位相調整器の並列補償部は, 自励式 SVC と同様に 変換器のゲートブロックやデブロックにより, 容易に系統 への併入，運転停止㧍よび解列が可能である。

一方，直列補償部は系統に直列に接続されているため， 変換器をゲートブロックすると変換器のフリーホイーリン グダイオードを介して系統の電流が直流回路に流れ込み, 直流りンク電圧の上昇による装置の破壊や系統の分断につ ながる。このため, 直列補賃部を停止するには, 変換器の ゲートブロックを行う以前に, 直列変圧器の系統側に接続 した遮断器 CB2 を投入することで系統電流をバイパスして おく必要がある。逆に, 起動を行う際には, ゲートデブロ ックの後に遮断器 $\mathrm{CB} 2$ を開放する。

$\langle 4 \cdot 2\rangle$ 潮流制御系統の潮流は, 臬列補顀部が出力 する補傾電圧 $V_{C}$ を調整することにより制御されるが，前記 の直列補僙部の動作モードにより制御結果が異なる。位相 変圧器モードおよび直列コンデンサモードでは, 補償電死 $\mathrm{V}_{\mathrm{C}}$ の位相が制限されているため， $\mathrm{V}_{\mathrm{C}}$ の大きさだけを制御 して有効電力潮流を制御する。この際, 無勃電力潮流は系 統の有効電力潮流を制御したことにより一義的に決定され る。これに対し，フリーモードでは補償電圧 $V_{\mathrm{C}}$ を自由に制 御できるため有効電力潮流之無勃電力潮流が独立に制御で きる。ただし，フリーモード動作により直列補償部が系綪 


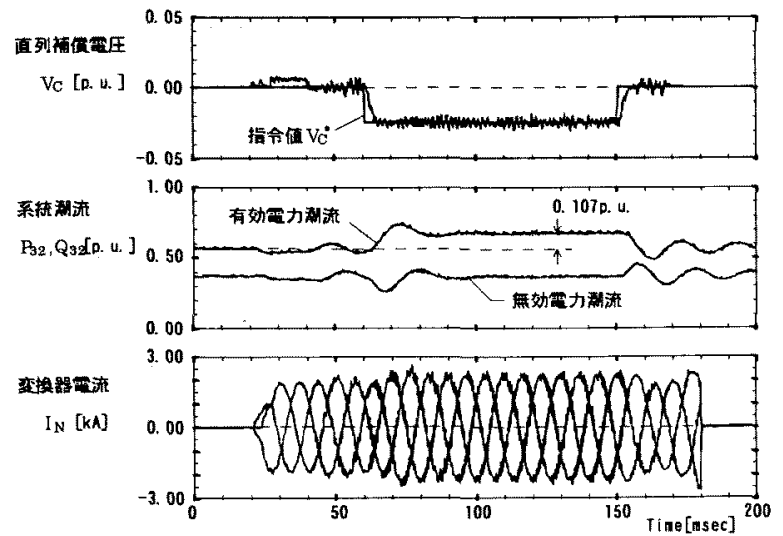

(a) 位相変圧器モード

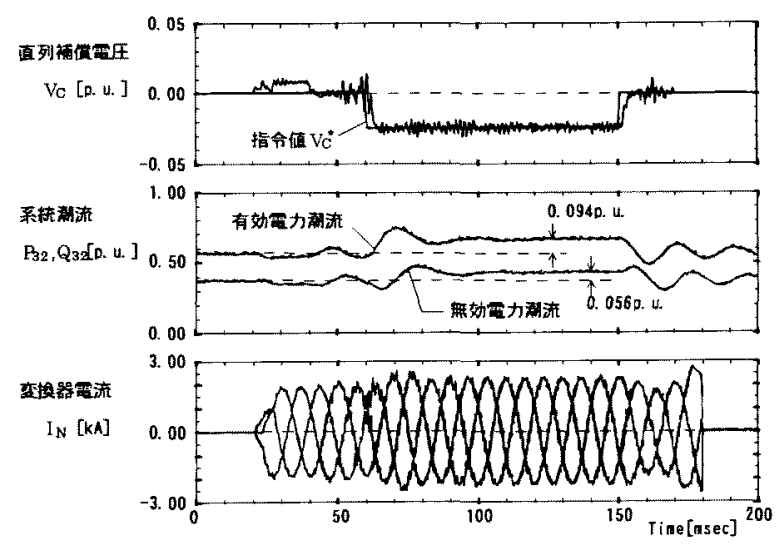

(b) 直列コンデンサモード

図 6 直列補償部の起動・停止

Fig.6. Waveforms of the UPFC in the start and stop operations.

と有効電力の授受を行うと，位相変圧器モードと同様に並 列補償部により直列補償部が系統と授受した有効電力を補 熕する必要がある。

$\langle 4 \cdot 3\rangle$ 定常運転に対する解析結果 図 5 に示した時 間シーケンスで直列補償部の起動と停止をシミュレーショ ンした波形を図 6 に示す。ここで, 図(a)は位相変圧器モ一 ド, 図(b)は值列コンデンサモードでの解析波形であり，時 刻 0 では並列補償部を既に起動させてある。

直列補償部において PWM 制御器の変調度を零として変 換器のゲートをデブロックしたのち, 時刻 $20 \mathrm{msec}$ の地点 で遮断器 $\mathrm{CB} 2$ を開放したことで, 直列補儐部の変換器電流 IN が流れはじめている。時刻 $40 \mathrm{msec}$ では直列補償電圧指 令 $V_{C}{ }^{*}=0$ として直列補償部の電王制御を動作させたことで, 直列補償電圧 $\mathrm{V}_{\mathrm{C}}$ が零に制御されている。その後の $\mathrm{V}_{\mathrm{C}}{ }^{*}$ のス テップ変化に対しては, $5 \mathrm{msec}$ 程度で $\mathrm{V}_{\mathrm{C}}$ が応答するとと もに, 位相変圧器モ一ドでは有勃電力 $\mathrm{P}_{32}$ が約 0.11 p.u. 增 加し, 直列コンデンサモードでは約 0.09p.u増加している。 時刻 $150 \mathrm{msec}$ 以降の停止動作では，直列補償電圧 $\mathrm{V}_{\mathrm{C}}$ を零 に絞った後に遮断器 $\mathrm{CB} 2$ を投入し，ゲートブロックにより 停止している。この結果から, 図 5 のシーケンスにより位
相変圧器モード, 直列コンデンサモードとも過電圧や過電 流を引き起こすことなく，起動・停止できることが確認さ れた。

直列補償電圧を変化させたとさの潮流の変化に関しては, $2 つ の$ 補償モード間で差異が生じている。直列補償電圧を 変化させたときの有効電力 $\mathrm{P}_{32}$ の変化幅は両補償モード間 で大きな差はないが，無勃電力 $\mathrm{Q}_{32}$ の変化幅は大きく異な る。位相変圧器モードでは, 直列補償電圧を変化させる前 と後とでは $Q_{32}$ は殆ど変化していない。これに対し，直列 コンデンサモードでは，約 0.06p.u.変化している。これは, 各補償モ一ドが出力する直列補償電圧の基準位相の違いが 系統への補償效果の違いとなって現れたものであり，一般 的に直列補堡電圧の変化に対して有効電力のみが応答する 位相変圧器モードの方が扱いやすい。ただし, 系統の力率 が高くなると両補貲モード間の差は䫓著ではなくなり, 力 率 1 ではほぼ同一となる。

\section{5. 系統事故時の過電圧・過電流抑制}

〈5・1〉バイパススイッチ並列補償部は自励式 SVC と同梯な構成であり，事故時の運転継続性について 様々な諭文で報告されている(6)。一方，直列補償部は系統 に直列に接続している構成上，系統事故により送電線に地 絡電流が流れると, 変換器にも地絡電流に対応した過電流 が流れる。そこで，送電線に流れる電流 Ic を検出し，装置 の定格電流を超えた過大な電流が流れると，図 2 に示すバ イパススイッチをオンして変換器を過電流から保護する。 万一, 変換器の故障などによる過電圧の発生時にも, それ を検出してバイパススイッチをオンすることにより，故障 の㹡大や系統の分離を防ぐことができる。バイパススイッ チのスイッチ素子には, VBO (Voltage Break Over) フリ 一光サイリスタが適している。VBO フリ一光サイリスタは, 所定の電圧でスイッチするようにブレークオーバ電圧が設 計された光トリガサイリスタである。このサイリスタの使 用により，万一の回路不動作時などに発生する過電圧を自 動的に抑制することが可能となる。

〈5・2〉解析モデル バイパススイッチによる直列 補償部の保護方式を採用するにあたっては, 特に過電圧・ 過電流を引起こすことなく，確実かつ短時間にバイパスス イッチが投入・開放され，変換器を保護できるかが重要之 なる。このような事項を険証するため, 図 1 ～図 3 に示し たシミュレーションモデルを使い, 次に示す代表的な 3 種 類の系統事故ケースについて解析を行った。

(1) 1回線3LG-3LO :

平衡故障に対する応動を確認するため，ノトト7にお いて 3 線地絡（3LG）を発生させ，70msec後に地絡 点の両端の括断器（CB67・CB78）年開放（3LO）す る。

(2) 1 回線1LG-1LO : 不平衡故障に対する応動を確認するため，ノド７に おいて 1 線地絡（1LG）を発生させ， $70 \mathrm{msec}$ 後に地 


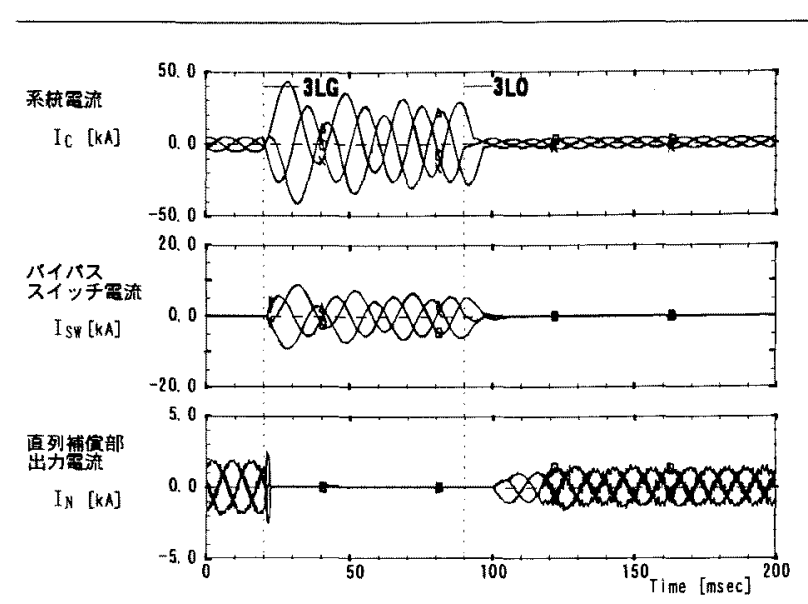

(a) 1 回線3LG-3L0

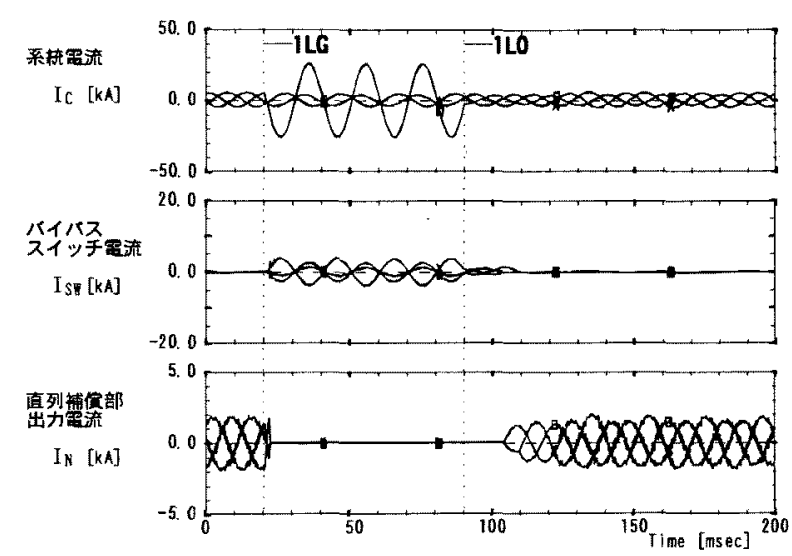

(b) 1 回線 1LG-1L0

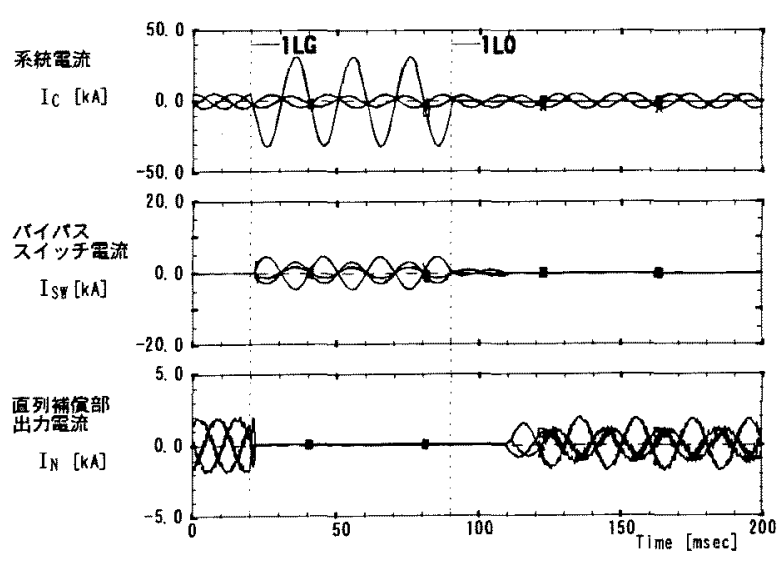

(c) 2 回線同相 $1 \mathrm{LG}-1 \mathrm{LO}$ (欠相事故)

図 7 系統事故時の電流波形

Fig.7. Waveforms of UPFC currents at system faults.

絡点の画端の遮断器 $(\mathrm{CB} 67 \cdot \mathrm{CB} 78)$ の当該相を開放 (1LO) する。

（3）2回線同相1LG-1LO（欠相事故）:

事故除去後に大きく不平衡が残るケースとして，2 回線同相1LG-1LO事故を想定する。ノ・・゙とノ・ド において同相 1 線地絡を発生させ, $70 \mathrm{msec}$ 後に地絡

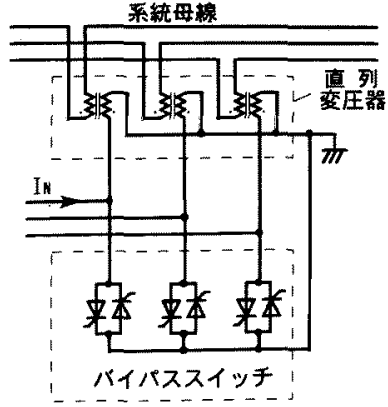

(a) スタ一結線

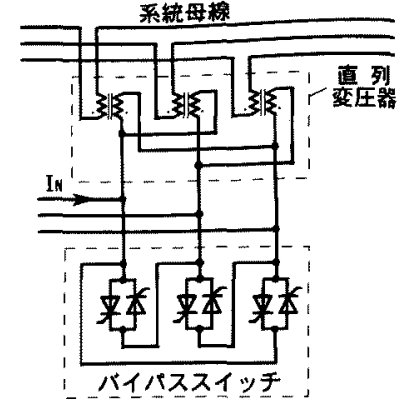

(b) デル夕結線
図 8 直列連系部の構成

Fig.8. Configurations of the series transformer and the bypass switches.

点の両端の遮断器 $\left(\mathrm{CB} 67 \cdot \mathrm{CB} 78, \mathrm{CB} 67^{\prime} \cdot \mathrm{CB} 78^{\prime}\right)$ の 当該相を開放する。

〈5・3〉 シミュレーション結果 事故ケース(1)〜 (3)の解析結果を図 7 に示す。事故発生により系統に地絡電 流が流れると，その電流を検出してバイパススイッチをオ ンすると共に淔列補償部の変換器をゲートブロックし, 事 故電流をバイパススイッチにバイパスさせている。事故点 が開放されたことにより系統電流が減少すると，ゲートブ ロックを解除するとともにバイパススイッチにオフ指令を 与え，その $20 \mathrm{msec}$ 後に電圧制御を開始している。事故後 の電力動摇の抑制を効果的に行うためには，可能な限り短 時間で定常運転状態へと復帰する必要がある。この復帰の ためにはバイパススイッチに流れる電流が完全に零となる のを待つ必要があり，バイパススイッチへのオフ指令と電 圧制御の開始間に $20 \mathrm{msec}$ の待ち時間を置いている。この 待ち時間は, 通常系統電圧の半周期以上が必要であるが, ここでは時間余裕をとって $20 \mathrm{msec}$ としている。

ケース 1 〜ケース 3 の事故形態の違いによる保菨性能の 差はなく, ビのケースでも過電圧・過電流を引起こすこと なく，良好な保護が行われている。

〈5・4〉バイパススイッチと直列変圧器の結線方式 装置の耐圧の锶点から変圧器の一方の巻線をスタ一結線と し，その中性点を直接接地することが一般的に行われる。 自励式位相調整器の直列変圧器では，1次巻線はオープン スター結線であるために接地できない。そのため図 8 (a)に 示すように 2 次側をスタ一結線として，その中性点を接地 することが考えられる。その際, 変換器用変圧器の中性点 も接地し，系統の零相電流をバイパスさせる必要がある。 この時のバイパススイッチの構成は，1アームのサイリス タが才ンすれば直列変圧器の 1 相が短絡できるように, 中 性点を接地したスター結線となる。しかしこの構成では， 系統事故時に重大な問題を引起こすことになる。

図 9 は, 直列変圧器の 2 次巻線を中性線付きのスタ一結 線とした場合についての, 図 7 (c)の事故ケース(3)と同一条 件での解析結果である。この解析ケースでは，事故点の開 


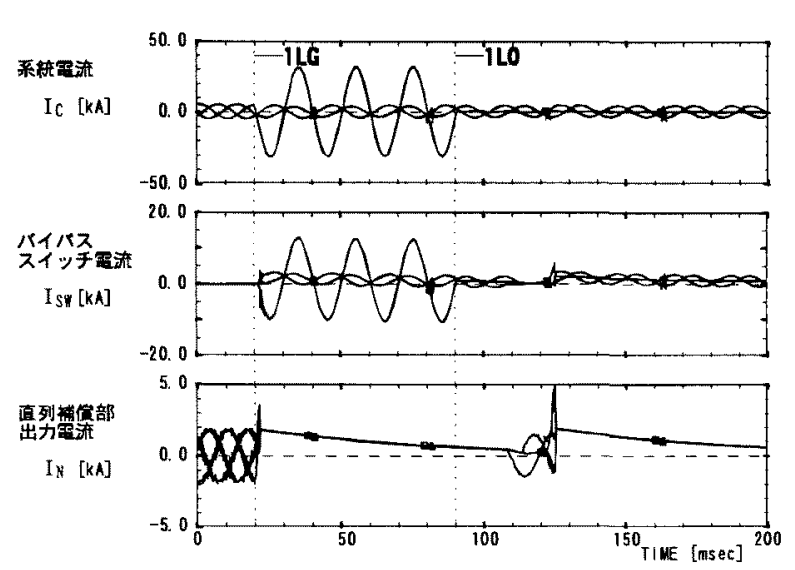

図 9 欠相事故時の電流波形（直列変圧器：ス夕一結線）

Fig.9. Waveforms of UPFC currents at system faults. (Series transformer : Y winding)

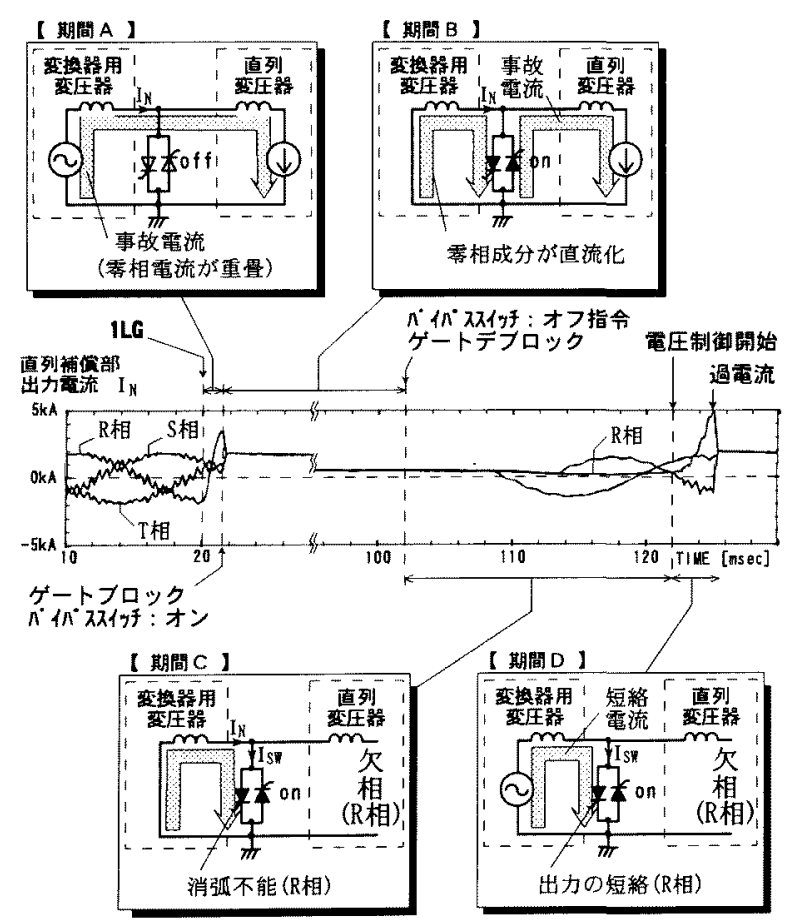

図 10 欠相事故時の回路動作

Fig.10. Circuit behavior during system faults.

放により系統電流 Ic が減少したことを検出してバイパスス イッチにオフ指令を与え, その $20 \mathrm{msec}$ 後に直列補償電圧 $\mathrm{V}_{\mathrm{c}}$ の制御を開始しているが，バイパススイッチが完全に才 フしていなかったために変換器の出力が短絡状態となり， その過電流を感知して再びバイパススイッチをオンした後 にゲートブロックしている。

図10は，図9の解析で生じた現象を説明した図である。 $1 \mathrm{LG}$ が発生する $20 \mathrm{msec}$ 以前では, 変換器用変圧器に流㣗 る直列補偵部の出力電流 IN に雾相成分の重畳はなく，3相
平衡した電流が流れている。時刻 $20 \mathrm{msec} に て 1 \mathrm{LG}$ が発生 したことにより, 期間 A では直列変生器を介して変換器用 変圧器の中性点には零相電流が流れ, 過電流となっている。 バイパススイッチ投入後の期間 Bでは, 変換器用変圧器零 相インピーダンスに含まれるインダクタンスに貯えられた エネルギにより，零相電流は減衰しながらも直流電流とし て流れ続ける。サイリスタにより構成さ机たバイパススイ ッチは，期間Cで示すように，オフ指令が与元られても直 流電流を遮断する能力はない。このため，期間Dにおいて オフできなかった相 (R相) で $\mathrm{V}_{\mathrm{C}}$ の制御開始時に出力が短 絡状態となり，再び過電流を発生させている。

本論文で検討しているように自劬式位相調整器の直列変 圧器の巻線を図 8 (b)に示すようなデル夕結線とすることで, 出力電流 $\mathrm{I}_{\mathrm{N}}$ への零相電流の重畳は無く，このような問題は 発生しない。

\section{6.むすび}

今回, 自励式位相調整器の起動・停止動作や定常運転動 作，系統事故時の動作について，特に直列補償部を中心に EMTP により瞬時值解析を行った。これにより，直列補償 部の起動および停止が，過電圧や過電流を引起こすことな く良好に行えることを示した。さらに，系統事故時の過電 圧・過電流から自励式位相調整器の直列㭪償部を保護する 方式として，サイリスタを使用したバイパススイッチによ る保護方式を检討した。この結果, 3LG-3LO，1LG-1LO, および久相事故においても良好な保護特性が得られた。

(平成8年10月25日受付, 同9年2月24日再受付)

\section{文献}

（1）嶋田 隆一：「パワーエレクトロニクス応用による新 送電システム」 電学誌, 112 巻 1 号, 平成 4 年

(2) 藤田, 紅林, 野原, 後藤: 「高速位相器によるループ 系統制御」 平成 5 年電気学会電力・エネルギー部門大 会, No.5

(3) L. Gyugyi, C. D. Schauder, K. K. Sen : "Static Synchronous Series Compensator A solid-state Approach to the Series Compensation of Transmission Line", IEEE, PES Winter Meeting, Paper No. 96 WM 120-6 PWRD, 1996

(4) B. T. Ooi, S.Z. Dai, F.D. Galiana : "A SOLID-STATE PWM PHASE-SHIFTER",IEEE Trans, on Power Delivery, Vol.8,No.2,pp.573-579 (April 1993)

(5) M. R. Iravani, P. L. Dandeno, K. H. Nguyen, D. Zhu, D. J. Maratukulam: "APPLICATIONS OF STATIC PHASE SHIFTERS IN POWER SYSTEMS",IEEE Trans. on Power Delivery, Vol.9,No.3,pp.1600-1608 (July 1994)

（6）常盤，市川，色川，北原：「電力系統用自励式 S V C の開発」 電学諭 $B, 113$ 巻 2 号, 平成5年 
（7）千田, 佐藤, 营原, 森川, 田村, 色川：「自励式位相 調整器の瞬時值解析による検討」電力技術・電力系統 技術合同研究会資料,PE-96-114;PSE-96-114,1996

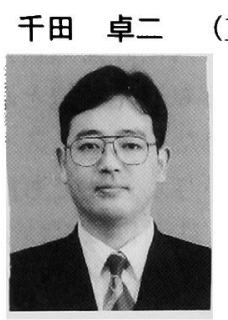

(正員)

1960 年 5 月 30 日生まれ。 198 3 年 3 月東京工業大学電気・電子工学科 卒業。同年 4 月東北電力(株)に入社。主 として電力系統の解析・制御に関する研 究に従事。現在, 同社研究開発センター 勤務。

\section{佐藤 佳彦 （正員）}

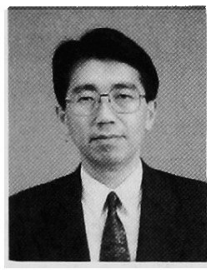

1955 年 7 月 9 日生まれ。 1980 年 3 月東北大学大学院工学研究科修士課 程修了。同年 4 月東北電力(株)に入社。 主として電力系統の制御技術・自動化シ ステムに関する技術業務に従事。現在, 同社電力システム部（制御技術）副長。

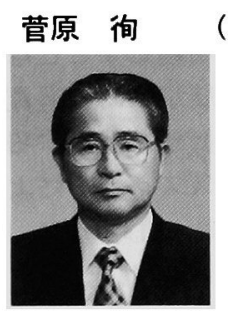

(正員)

1937 年 9 月 24 日生まれ。 19 62 年 3 月岩手大学電気工学科卒業。 同年 4 月東北電力(株)に入社。主として 電力系統保護・安定化に関する技術業 務に従事。現在, 同社電力システム部 部長。

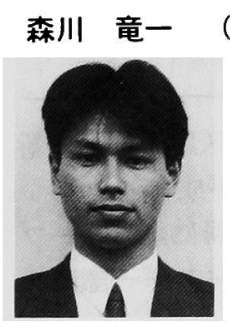

1967 年 12 月 2 日生。1992 年 3 月大分大学大学院工学研究科電子 工学専攻修士課程修了。同年 4 月(株)東 芝に入社。主として電力用パワーエレ クトロニクス装置の研究開発に従事。 現在, 同社重電技術研究所勤務。

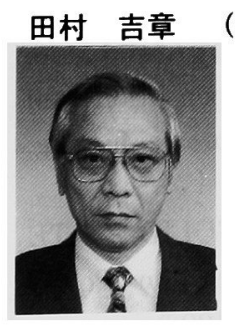

942 年 12 月 13 日生。196 8 年 3 月早稲田大学理工学研究科電気 工学専攻修士課程修了。同年 4 月東京 芝浦電気(株)入社。主としてパワーエレ クトロニクス，半導体製造装置等の研 究開発に従事。現在, エレクトロニク 又技術開発部主幹。工学博士。

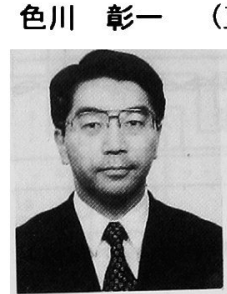

(正員)

1950 年 3 月 30 日生。 1975 年 3 月早稲田大学理工学研究科電気工 学専攻修士課程修了。同年 4 月(株)東芝 に入社。主として直流送電, S V C の 開発に従事。現在, 電力変電技術部主 幹。1988 年論文賞。I E E E 会員。 